\title{
Rape by Nonphysical Coercion: State v. Brooks
}

\author{
Elizabeth Hanus*
}

\section{INTRODUCTION}

What is and is not considered rape is far from clear. For instance, which of these threats, if any, are criminal under rape law?

- "If you don't have sex with me, I'm going to file for divorce, get custody of the kids, and you will never see them again."

- "If you don't have sex with me, I'm going to report you to immigration."

- "If you don't have sex with me, I'm going to break up with you."

Currently, none of these threats would be captured under rape laws in many jurisdictions in the United States. ${ }^{1}$ However, based on the Kansas Supreme Court's interpretation of section 21-5503 of the Kansas Criminal Code in State v. Brooks, a defendant could be guilty of rape if the victim was "overcome by fear" due to any of these threats.

Under section 21-5503, a person is guilty of rape for "[k]nowingly engaging in sexual intercourse with a victim who does not consent to the sexual intercourse ... [w] hen the victim is overcome by force or fear." ${ }^{3}$ In Brooks, the court held that fear is not limited to fear of physical threats, but rather fear is "a highly subjective concept that does not lend itself to definition as a matter of law." Applying this "highly subjective" standard,

\footnotetext{
* J.D. Candidate, 2017, University of Kansas School of Law; B.A. Economics 2007, Macalester College. I would like to thank Professor Yung for his helpful feedback and guidance throughout the writing process and the members of the University of Kansas Law Review for their hard work and help in publishing this Comment. I would also like to thank my family and friends for their constant encouragement and support.

1. See Model Penal Code: Sexual Assault and Related Offenses $\$ 213.4(1) \mathrm{cmt}$., at 70 (AM. LAW INST., Discussion Draft No. 2, 2015) [hereinafter MPC DRAFT] ("[M]any states (possibly the majority) continue to restrict... sexual offenses to situations involving threats of physical violence.").

2. See State v. Brooks, 317 P.3d 54, 65 (Kan. 2014) (refusing to qualify the term fear and holding "whether a victim is overcome by fear... is generally a question to be resolved by the finder of fact").

3. KAN. Stat. ANN. § 21-5503(a)(1)(A) (Supp. 2015).

4. Brooks, 317 P.3d at 63 (emphasis added) (quoting State v. Tully, 262 P.3d 314, 331 (Kan. 2011)).
} 
the court affirmed the defendant's rape conviction, holding that there was sufficient evidence that the victim - the defendant's ex-wife - was overcome by fear due to his threats to expose an affair she had had with a married coworker. ${ }^{5}$

Although the defendant's conduct in Brooks was reprehensible-and this Comment will argue appropriately criminalized - the highly subjective standard is an unsatisfactory way to criminalize rape by nonphysical coercion. This standard, or rather lack of a standard, is too broad and could lead to a lack of predictable results and an over-criminalization of conduct. In certain circumstances, nonphysical coercion should be criminalized under rape law. The challenge, however, is how the law should define those circumstances. When does a person's conduct cross the line from permissible persuasion, or even a morally suspect but legal threat, to illegal coercion that is appropriately criminalized under rape law?

Drawing from laws in states that criminalize rape by nonphysical coercion and approaches suggested by scholars, this Comment proposes a blended, incremental approach to criminalizing rape by nonphysical coercion. This approach would criminalize threats that leave a person with no reasonable alternative but to engage in the sex act. Specifically, rape by nonphysical coercion would include: (1) context-specific circumstances in which there would be a rebuttable presumption that the threatened person had no reasonable alternative, and thus, the threat was illegal and (2) a general category criminalizing emotional, psychological, intellectual, or moral threats ${ }^{6}$ that leave the person no reasonable alternative but to engage in the sex act. This approach would provide Kansas with a more clearly defined standard that would lead to more predictable results and better guide behavior, as illustrated in Part III of this Comment. First, however, Part II of this Comment provides an overview of rape law and its underlying foundations, followed by a discussion of existing and proposed laws governing rape by nonphysical coercion and the Brooks case. Part III analyzes the court's holding in Brooks and alternative approaches presented by scholars. Finally, Part III proposes a blended, incremental approach to criminalizing rape by nonphysical coercion, followed by an application and discussion of the proposed approach.

5. Id. at $65-66$.

6. The descriptions of these types of threats are based on the definition of "forcible compulsion" as the phrase is used in Pennsylvania's rape statute. See 18 Pa. Cons. STAT. $\$ \S 3101$, 3121 (Supp. 2014). 


\section{BACKGROUND}

An overview of the history of rape law and a summary of the current law is helpful in understanding where Brooks fits within the broader context of rape law. Part A of this section provides a summary of rape law: its history, foundations, and where it stands today. Part B reviews existing laws, or the lack of laws, governing rape by nonphysical coercion, as well as proposed alternatives. Part $\mathrm{C}$ discusses the Brooks case.

\section{A. Rape Laws Generally}

\section{History and Foundations of Current Rape Law}

Rape has been a crime for thousands of years, dating back to ancient codes and Roman law. ${ }^{7}$ However, until the mid-twentieth century, the crime of rape was largely focused on protecting men's property rights - their property being women. ${ }^{8}$ Under Roman law, a rapist was liable to the victim's father, husband, or brother. ${ }^{9}$ Under early English common law, the rape of a virgin - more valuable property - was viewed as a more serious offense than the rape of a non-virgin. ${ }^{10}$ Aspects of the law continued to reflect this focus on protecting male interests well into the twentieth century. ${ }^{11}$ Only women could be raped, and a husband could not rape his wife. ${ }^{12}$ Resistance —often "utmost resistance" — was a required element of rape. ${ }^{13}$

Beginning in the 1970s, American rape law began to undergo a reform in response to criticisms by feminists such as Susan Brownmiller, Susan

7. Donald A. Dripps, Beyond Rape: An Essay on the Difference Between the Presence of Force and the Absence of Consent, 92 CoLuM. L. REV. 1780, 1780-81 (1992); see also Katherine K. Baker, Why Rape Should Not (Always) Be a Crime, 100 MinN. L. REv. 221, 225 (2015) ("The first known prohibition on rape appears in Hammurabi's Code and dates from 1900 B.C.").

8. See Corey Rayburn Yung, Rape Law Fundamentals, 27 YALE J.L. \& Feminism 1, 15 (2015) ("Rape became a crime solely because of male interests in their current or prospective spouses."); Baker, supra note 7, at 225-26 ("Monetary compensation for rape follows logically when women are viewed as property because rape causes economic injury to the men who own women.").

9. Dripps, supra note 7, at 1781-82.

10. Id. at 1782 .

11. See infra notes $15-16$ and accompanying text.

12. See Yung, supra note 8, at 15 (explaining that pre-reform era rape laws held that rape occurred "between a man and a woman who is not his wife").

13. Id. at 15. And to meet this utmost-resistance requirement, "victims had to resist a sexual assault to their dying breath" or there was no rape. Id. 
Griffin, and Catherine MacKinnon. ${ }^{14}$ There were both substantive and procedural changes. Substantively, rape became a gender-neutral crime, the resistance requirement was removed from nearly all statutes, and marital rape became a crime. ${ }^{15}$ Procedurally, rape-shield laws were enacted and corroboration requirements were eliminated. ${ }^{16}$

Underlying these changes was an evolving understanding of the crime of rape. Rape is no longer seen as a crime against property or a simple battery. ${ }^{17}$ Rape is something more. Today, rape is widely understood as a violation of sexual autonomy. ${ }^{18}$ Every person has a right to "choose freely whether and when to be sexually intimate with another person." " However, given that sex is a mutual activity, sexual autonomy has inherent limits. ${ }^{20}$ Having consensual sex with another person depends on the other person also exercising control over their autonomy and choosing to have sex. In other words, sexual autonomy has both a negative dimension-freedom from unwanted sex-and a positive dimension-freedom to pursue a sexual relationship that is mutually desired. ${ }^{21}$ Rape, then, is a violation of the negative dimension of sexual autonomy. ${ }^{22}$

In addition to autonomy, Professor Corey Rayburn Yung outlines three other justifications for treating rape as a distinct crime: harm, gender, and terror. ${ }^{23}$ Rape is unique in terms of both the type and severity of harm it causes. ${ }^{24}$ Rape is more than just a physical attack. ${ }^{25}$ Compared to victims of

14. See Stephen J. Schulhofer, Unwanted Sex: The Culture of Intimidation and the FAILURE OF LAW 25, 29-30 (1998) [hereinafter SCHULHOFER, UNWANTED SEX].

15. Yung, supra note 8 , at 15.

16. Schulhofer, Unwanted SeX, supra note 14, at 33. Rape-shield laws limit the scope of cross-examination of the victim regarding his or her prior sexual relationships. Id. at 30. Under corroboration requirements that were previously in place, convictions were barred "unless independent witnesses or physical evidence corroborated the victim's testimony." Id. at 18.

17. See Yung, supra note 8, at 20-21 (describing the "greater and different harm" caused by rape as opposed to "ordinary batteries"); see also Dripps, supra note 7, at 1783 (explaining the shift of viewing rape as a crime violating a man's possession of a woman-i.e., a property crime - to a crime that violates sexual autonomy).

18. MPC DRAFT, supra note $1, \S 213.4(1) \mathrm{cmt}$, at 70; see also Baker, supra note 7, at 228 ("Overriding the victim's will that she not be touched in that particular area by that particular person constitutes the gravamen of rape. It is that act of disregarding her will that violates women's sexual autonomy.").

19. MPC DRAFT, supra note 1, general commentary, at 16.

20. Yung, supra note 8, at 28.

21. Stephen J. Schulhofer, Rape-Law Reform Circa June 2002: Has the Pendulum Swung Too Far?, 989 ANNALS N.Y. ACAD. SCI. 276, 277 (2003).

22. $I d$.

23. Yung, supra note 8 , at 20 .

24. Id. at 20-22.

25. Id. at 20 . 
other violent crimes, rape victims are significantly more likely to suffer physiologically and psychologically from the rape. ${ }^{26}$ Even today, rape victims continue to be stigmatized and treated differently than other crime victims. ${ }^{27}$

Although rape is now a gender-neutral crime from the perspective of the law, it continues to be closely interwoven with gender dynamics. ${ }^{28}$ Rape victims are primarily women and most perpetrators are men. Based on the National Crime Victimization Survey conducted by the Bureau of Justice Statistics, between 1995 and 2010, 91\% of all recorded rape or sexual assault victimizations involved female victims. ${ }^{29}$ Whereas in 2014, men comprised $97 \%$ of the arrests for rape according to the FBI Uniform Crime Reports. ${ }^{30}$ Understanding rape as a crime of gendered violence and reflective of broader social misogyny provides an additional foundation for treating rape as a distinct crime. ${ }^{31}$

Finally, rape is different from many other crimes given its broader effect of creating an "atmosphere of terror." ${ }^{, 32}$ While it is not possible to determine an exact number of individuals that experience sexual assault, various studies have found that as many as one in five female college students in the U.S. experience sexual assault. ${ }^{33}$ Even while acknowledging that the

26. Id. at 21; see also Carlo Faravelli et al., Psychopathology After Rape, 161 AM. J. PSYCHIATRY 1483, 1483-84 (2004) (finding women who were raped were significantly more likely to suffer from PTSD and major depression compared to victims of other life-threatening traumas such as violent robberies and physical assaults); Rebecca Campbell et al., An Ecological Model of the Impact of Sexual Assault on Women's Mental Health, 10 Trauma, Violence, \& ABUSE 225, 225-26 (2009) (citing numerous studies reflecting the high prevalence of negative, mental-health conditions suffered by women with a history of sexual assault).

27. See Yung, supra note 8, at 21-22 (discussing the isolating impact of social sanctions, such as victim blaming, on rape victims).

28. Id. at 25; see also Patricia J. Falk, Not Logic, but Experience: Drawing on Lessons Learned from the Real World in Thinking About the Riddle of Rape-by-Fraud, 123 YALE L.J. ONLINE 353, 359 (2013), http://www.yalelawjournal.org/pdf/1223_pr5jmvli.pdf ("Despite the gender-neutral language in most modern rape statutes, it is true that the vast majority of rape victims are women and the vast majority of perpetrators of forcible rape are men." (footnotes omitted)).

29. Michael Planty et al., U.S. Dep’t of Justice, Female Victims of Sexual Violence, 1994-2010 3 (2013), http://www.bjs.gov/content/pub/pdf/fvsv9410.pdf. "In 2010, the male rate of rape or sexual assault was 0.1 per 1,000 males compared to a rate of 2.1 per 1,000 females." Id. (citation omitted).

30. See Ten-Year Arrest Trends, THE FBI, https://www.fbi.gov/about-us/cjis/ucr/crime-in-theu.s/2014/crime-in-the-u.s.-2014/tables/table-33 (last visited Mar. 11, 2016) (reporting 9,757 total rape offenses charged, with 9,449 committed by male perpetrators versus 308 committed by female perpetrators).

31. Yung, supra note 8, at 25 .

32. Id. at 26 (describing studies and anecdotal accounts that demonstrate the ways in which the fear of rape affects individuals' day-to-day decisions).

33. Scott Jaschik, 1 in 5 After All?, INSIDE HigheR ED (June 15, 2015), 
statistic is limited to females in college, that sexual assault is broader than rape, and that the studies may overstate (or understate) the actual percentage due to various methodological factors, the number is striking. These types of statistics indicate that the fear of rape or sexual assault affects a much broader population than just direct victims-creating an atmosphere of terror. ${ }^{34}$

Understanding the history and foundations of rape law helps to not only provide for a more comprehensive understanding of current rape law, but also helps to inform and contribute to the ongoing development of the law. For, despite the gains from reforms over the last forty years, rape law continues to be a unique area of the law where many problems persist. ${ }^{35}$ For example, despite changes in their respective laws, a comprehensive study of Georgia, Illinois, Michigan, Pennsylvania, Texas, and Washington, D.C. showed that there was no increase in conviction rates. ${ }^{36}$ Consistent with this, there was also little change in the way police officers, prosecutors, and judges approached rape cases. ${ }^{37}$ Thus, despite the progress made, there continues to be a need for further reform.

\section{Current Rape Law}

Under current rape law there are either three (sex act, non-consent, and force) or two (sex act and non-consent) elements. ${ }^{38}$ Before summarizing rape laws across the U.S., however, a caveat is necessary. Given the variation in rape laws across states, and in many instances a lack of case law interpreting the statutes, an initial statutory survey can be misleading. ${ }^{39}$ For

https://www.insidehighered.com/news/2015/06/15/new-survey-finds-1-5-college-women-haveexperienced-sexual-assault.

34. Yung, supra note 8, at 26-27.

35. See id. at 38-39, 42 (discussing current problems in rape law such as the high prevalence of sexual violence in the U.S. and the failure of law enforcement and prosecutors to enforce rape and sexual assault laws).

36. SCHUlHOFER, UNWANTED SEX, supra note 14, at 38. In the study, "[t]he researchers concluded that the impact of reform, in all six jurisdictions, was "minimal."' Id. (citing Cassia Spohn \& Julia Horney, The Impact of Rape Law Reform on the Processing of Simple and Aggravated Rape Cases, 86 J. CRIM. L. \& CRIMINOLOGY 861, 863 (1996)).

37. Id. For example, even if the new statute did not include a resistance requirement, police, prosecutors, and judges still considered whether a victim resisted to be important. Id.

38. See John F. Decker \& Peter G. Baroni, "No" Still Means "Yes": The Failure of the "NonConsent" Reform Movement in American Rape and Sexual Assault Law, 101 J. CRIM. L. \& CRIMINOLOGY 1081, 1083-86 (2011) (describing classification of different state laws based on the elements included in the statutes).

39. See MPC DRAFT, supra note 1, § 213.1(2) cmt., at 36-37 (describing the challenges in conducting a statutory survey of existing rape law across all states); see also Decker \& Baroni, supra note 38, at 1084 (classifying states based on the elements in each states' rape laws and including a 
example, some states appear not to include a force element. ${ }^{40}$ Non-consent, however, is then defined by showing forcible compulsion or an incapacity to consent. ${ }^{41}$ In addition, some states do not require a showing of force for sexual contact offenses, but require force for sexual penetration offenses. ${ }^{42}$ As a result, the summary that follows is approximate.

Rape law can be divided between states that include a force requirement and states that do not. ${ }^{43}$ Slightly less than half of states do not require force. $^{44}$ In these states, sexual penetration without consent is a felony. ${ }^{45}$ However, the definitions of consent or lack of consent vary across jurisdictions. ${ }^{46}$ Some states define consent in an affirmative manner, with the absence of consent being a lack of positive cooperation. ${ }^{47}$ Other states define consent in the negative, with non-consent being an expression, which can be verbal or nonverbal, indicating unwillingness or lack of consent. ${ }^{48}$ In addition, many states recognize certain situations in which an individual may be unable to consent due to factors such as mental incapacity or

category for "contradictory non-consent states" that appear not to include a force element but define non-consent by a showing of forcible compulsion or an incapacity to consent). 36.

40. Decker \& Baroni, supra note 38, at 1085; MPC DRAFT, supra note 1, § 213.1(2) cmt., at

41. Decker \& Baroni, supra note 38, at 1085. For example, Alaska's sexual assault statutes do not appear to include a force element. See, e.g., ALASKA STAT. § 11.41 .410 (2007) ("An offender commits the crime of sexual assault in the first degree if (1) the offender engages in sexual penetration with another person without consent of that person ...."). Without consent, however, is then defined to mean that a person "(A) with or without resisting, is coerced by the use of force against a person or property, or by the express or implied threat of death, imminent physical injury, or kidnapping to be inflicted on anyone; or (B) is incapacitated as a result of an act of the defendant." Id. § 11.41.470(8) (2007) (emphasis added).

42. Decker \& Baroni, supra note 38, at 1087. Minnesota's fifth-degree, sexual-conduct statute, for example, states that: "A person is guilty of criminal sexual conduct in the fifth degree if the person engages in non-consensual sexual contact.' Conversely, all of Minnesota's other sex offenses, including penetration offenses, require a showing of force, threat of force, coercion, or deception.” Id. (footnotes omitted); see also MINN. STAT. §§ 609.341-.3451 (2009 \& Supp. 2014).

43. Decker \& Baroni, supra note 38 , at 1084.

44. See id. (classifying twenty-eight states as "true non-consent states," but noting that only seventeen of these states have non-consent provisions for sexual-penetration offenses); see also MPC DRAFT, supra note $1, \S 213.2(1)(a) \mathrm{cmt}$., at 44 ("At present 17 states provide a felony punishment for sexual penetration on the basis of lack of consent alone, without requiring added showings of coercion, force, deception, or other special situations and without defining 'nonconsent' in such a way as to require force or high levels of resistance.").

45. MPC DRAFT, supra note 1, § 213.2(1)(a) cmt., at 44.

46. See id. § 213.2(1)(a) cmt., at 44-45 (discussing various consent definitions); see also Decker \& Baroni, supra note 38, at 1084-1101 (discussing non-consent and consent-based state laws).

47. MPC DRAFT, supra note $1, \S 213.2(1)(a) \mathrm{cmt}$., at 44; see also Decker \& Baroni, supra note 38, at 1088-90 (discussing different statutory definitions of consent).

48. MPC DRAFT, supra note $1, \S 213.2(1)$ (a) cmt., at 44-45; Decker \& Baroni, supra note 38, at $1088-90$. 
intoxication. $^{49}$

In the slight majority of states that include force as an element in sexualpenetration offenses, there is also substantial variation in the definition of force - both in terms of the amount and type of force required. ${ }^{50}$ Eight states require significant physical force. ${ }^{51}$ For example, first-degree, forcible rape in North Carolina requires that the offender employ or display "a dangerous or deadly weapon" or inflict "serious personal injury upon the victim or another person." extrinsic to the sex act-i.e., some amount of force beyond the force inherent in the act of nonconsensual sex. ${ }^{53}$ Some states have also expanded force to include constructive or implied force, including threats of physical violence or situational factors such as physical size differentials and isolation. ${ }^{54}$

Finally, there is variation as to what sex acts constitute rape. Although all states include vaginal penetration by a penis, whether penetration by other body parts or objects is included or if anal or oral sex is included varies across states. ${ }^{55}$ Thus, despite the commonality of the elements across different jurisdictions, there is considerable variation in what constitutes rape.

49. For example, in Kansas, the definition of rape includes:

Knowingly engaging in sexual intercourse with a victim when the victim is incapable of giving consent because of mental deficiency or disease, or when the victim is incapable of giving consent because of the effect of any alcoholic liquor, narcotic, drug or other substance, which condition was known by the offender or was reasonably apparent to the offender....

KAN. STAT. ANN. § 21-5503(a)(2) (Supp. 2015) (emphasis added).

50. MPC DRAFT, supra note $1, \S 213.1(2) \mathrm{cmt}$., at 36.

51. Id. $\S 213.1(2) \mathrm{cmt}$., at $37 \mathrm{n} .86$. These states include: "Maine, Montana, North Carolina, Iowa, South Carolina, Texas, Indiana, and Louisiana." Id.

52. N.C. GEN. STAT. § 14-27.21(a)(1)-(2) (2000).

53. See MPC DRAFT, supra note 1, § 213.1(2) cmt., at 37-38 (discussing states' force requirements).

54. Id. § 213.1(2) cmt., at 38-39.

55. For example, in Kansas, sexual intercourse, as used in the rape statute, is defined as: "any penetration of the female sex organ by a finger, the male sex organ or any object." KAN. STAT. ANN. $\S \S 21-5501(a),-5503$ (2008 \& Supp. 2015). Sodomy is defined as: "oral contact or oral penetration of the female genitalia or oral contact of the male genitalia; anal penetration ... of a male or female by any body part or object...."Id. § 21-5501(b). Although sodomy is separately criminalized in section 21-5504, the language and classification of the level of the offense is generally similar to the rape statute. Compare id. § 21-5503, with id. § 21-5504. 


\section{B. Rape by Nonphysical Coercion}

\section{Current Laws}

This variation continues when examining the narrower category of rape by nonphysical coercion. ${ }^{56}$ The first major distinction between jurisdictions is whether rape by nonphysical coercion is criminalized. ${ }^{57}$ Many states do not criminalize rape by nonphysical coercion and restrict rape to situations involving violence or threats of physical violence. ${ }^{58}$ However, the legislatures in several states have broadened the scope of their statutes to include rape by nonphysical coercion. ${ }^{59}$ Within these states, the legislatures vary in categorizing and grading the offense. Some states incorporate nonphysical coercion into existing rape statutes, whereas others create new offenses that carry lighter penalties than rape. ${ }^{60}$

There is also variation as to specifically what type of conduct constitutes criminal nonphysical coercion. Though no two statutes are identical, the following common definitional approaches emerge when analyzing existing statutes: (1) inclusion or exclusion of an objective or reasonable-person standard; (2) either using broad, typically undefined terms such as coercion or extortion, or enumerating behaviors constituting unlawful conduct; and

56. See Decker \& Baroni, supra note 38, at 1120-22 (dividing the eighteen states that include some type of non-physical threat in their rape statutes into three categories: (1) "Threat of Use of Force Against Property;" (2) "Extortion, Intimidation, Public Humiliation, or Undefined 'Coercion;" and (3) "Comprehensive Statutes"); see also MPC DRAFT, supra note 1, § 213.4(1) cmt., at 70-71 (discussing variations).

57. Decker \& Baroni, supra note 38, at 1119-20; MPC DRAFT, supra note $1, \S 213.4(1) \mathrm{cmt}$, at $70-71$.

58. MPC DRAFT, supra note $1, \S 213.4(1) \mathrm{cmt}$., at 70.

59. Id. $\S 213.1(2) \mathrm{cmt}$., at 39 . As noted in the commentary to the draft MPC:

A handful of states go beyond physical force or domination to penalize forms of coercion that are purely psychological or exploitive in nature. Formulations along these lines include statutes that penalize intercourse obtained by:

- "extortion," "intimidation," or "coercion"

- "threats of public humiliation or intimidation"

- threats to accuse the victim or any other person of a crime

- threats to "expose a secret or publicize an asserted fact, whether true or false, tending to subject any person to hatred, contempt or ridicule."

- "a threat, express or implied, that places a person in fear of public humiliation, property damage, or financial loss."

- "use of physical, intellectual, moral, emotional, or psychological force, either express or implied."

Id. (footnotes omitted). See also Decker \& Baroni, supra note 38, at 1120-22 (discussing states with non-physical-coercion statutes); Patricia J. Falk, Rape by Fraud and Rape by Coercion, 64 BROOK. L. REV. 39, 119-25 (1998) [hereinafter Falk, Rape] (discussing non-physical coercion).

60. See infra notes 62-67 and accompanying text. 
(3) criminalizing sexual activity, including activity due to nonphysical coercion, in certain contexts where one person holds a position of trust or power, such as teachers or psychotherapists. ${ }^{61}$

For example, Pennsylvania includes nonphysical coercion in its rape statute using relatively broad terms. In Pennsylvania, rape includes engaging in sexual intercourse with a person by "forcible compulsion" or by "threat of forcible compulsion that would prevent resistance by a person of reasonable resolution." 62 Forcible compulsion is defined as "[c]ompulsion by use of physical, intellectual, moral, emotional or psychological force, either express or implied." ${ }^{\prime 63}$ For threats of forcible compulsion, an objective standard is added by requiring that the threat would "prevent resistance by a person of reasonable resolution." 64

On the contrary, Delaware has a separate offense of sexual extortion-a class $\mathrm{E}$ felony punishable by up to five years in prison. ${ }^{65}$ A person is guilty of sexual extortion if the person causes another person to engage in a sex act by threatening to do any of the following:

(1) Cause physical injury to anyone;

(2) Cause damage to property;

(3) Engage in other conduct constituting a crime;

(4) Accuse anyone of a crime or cause criminal charges to be instituted against anyone;

(5) Expose a secret or publicize an asserted fact, whether true or false, intending to subject anyone to hatred, contempt or ridicule;

(6) Falsely testify or provide information or withhold testimony or information with respect to another's legal claim or defense; or

(7) Perform any other act which is calculated to harm another person materially with respect to the other person's health, safety, business, calling, career, financial condition, reputation or personal

61. See infra notes 62-67 and accompanying text; see also Falk, Rape, supra note 59, at 79-84 (discussing rape-by-coercion cases involving situations "in which a defendant uses an authoritative position or manipulates a power relationship to achieve sexual compliance").

62. 18 PA. CONS. STAT. § 3121(a) (Supp. 2014).

63. Id. § 3101 (Supp. 2014).

64. Id. § 3121(a)(2).

65. Del. CoDE ANN. tit. 11, §§ 774, 4205 (2006 \& Supp. 2016). 
relationships. ${ }^{66}$

In comparison, first-degree rape in Delaware-a class A felony punishable by a minimum of fifteen years and up to a maximum of life in prison-includes sexual intercourse without the victim's consent if "the person causes physical injury or serious mental or emotional injury to the victim" during the commission of the crime. ${ }^{67}$ Though the rape statute includes serious mental or emotional injury, the sexual-extortion statute's more expansive list of nonphysical threats is not included in the more harshly penalized crime of rape.

\section{Lack of Enforcement of Current Laws}

Although states vary considerably as to how, if at all, rape by nonphysical coercion is criminalized, there is one area where states are largely consistent - the lack of case law involving rape by nonphysical coercion. ${ }^{68}$ Even states that criminalize this type of conduct lack case law on the topic. ${ }^{69}$ And the majority of the limited case law that does exist consists of cases that involve minors or include threats of force ${ }^{70}$ Various factors likely contribute to the under-enforcement of rape-by-nonphysical coercion laws.

Professors John F. Decker and Peter G. Baroni note that the lack of case law suggests that: (1) states are not prosecuting these offenses; (2)

66. Id. $\S 774$. All the impermissible threats included in Delaware's sexual-extortion statute are also included in Delaware's extortion statute, which is also a class E felony. Id. $\S \S 774,846$. Under Delaware's extortion statute, a person is guilty of extortion if the person causes another person to deliver property to them by threatening one of the enumerated acts. Id. $\S 846$. In addition to its general extortion statute, Delaware also criminalizes coercion - a class A misdemeanor publishable by up to one year in prison. Id. $\S \S 791,4296$. A person is guilty of coercion if the person causes another person to "engage in conduct which the victim has a legal right to abstain from in engaging in" by threatening one of the enumerated acts. Id. § 791 .

67. Id. $\S \S 773,4205$ (emphasis added).

68. Decker \& Baroni, supra note 38 , at 1122-23.

69. Id.

70. Id.; see, e.g., Sutton v. Commonwealth, 324 S.E.2d 665, 672 (Va. 1985) (affirming rape conviction where defendant raped his fifteen-year-old, physically handicapped niece by threatening to return her to her physically abusive father); State v. Meyers, 799 N.W.2d 132, 146 (Iowa 2011) (affirming third-degree sexual abuse conviction where defendant had sex with his teenage stepdaughter while she was in a "very vulnerable psychological state ... due to her crack cocaine addiction, her estrangement from her mother, and her need for support and shelter"); Sabol v. Commonwealth, 553 S.E.2d 533, 537-38 (Va. Ct. App. 2001) (reversing rape conviction where defendant had sex with his stepdaughter by threatening to have her prosecuted for taking money out of her mother's bank account without permission, but affirming rape conviction where defendant pushed her down a hallway to a bedroom where he raped her). 
defendants are being prosecuted, but acquitted; or (3) defendants are being convicted, but opting not to appeal. ${ }^{71}$ While possible, it seems unlikely that large numbers of defendants are being convicted and not appealing. ${ }^{72}$ More likely, the lack of case law reflects a lack of prosecutions, or it reflects prosecutions but a lack of convictions. ${ }^{73}$

The lack of either prosecutions or convictions may be a function of multiple factors. Professors Decker and Baroni point to the lack of clarity in the existing laws. ${ }^{74}$ "Without a clear definition of the parameters of a law, courts and prosecutors cannot adequately enforce it." $" 75$ The lack of clearly defined terms in statutes, coupled with limited case law, results in ambiguity as to just what behavior is criminal. Professors Decker and Baroni also note that when states criminalize nonphysical coercion as a low-level misdemeanor, the legislatures signal that they are not taking rape by nonphysical coercion as seriously as rape involving physical force. ${ }^{76}$

The lack of enforcement of rape by nonphysical coercion laws is also likely part of the broader under-enforcement of all rape law. As noted by Professor Yung when discussing rape generally, "rape is incredibly underreported, reported rapes are not regularly investigated, arrests in rape cases are rare, prosecutors are loath to take rape cases that might jeopardize their high conviction rates, and convictions at trial are less likely than in other crimes." 77 This lack of enforcement may be amplified when criminalizing a broader scope of conduct such as rape by nonphysical coercion.

Similarly, expanding the scope of rape laws too far beyond generally accepted social norms of what constitutes rape may actually reinforce existing norms and result in less enforcement. ${ }^{78}$ Professor Dan M. Kahan

1. Decker \& Baroni, supra note 38 , at 1125.

72. Id.

73. See id.

74. Id.

75. Id.

76. Id.

77. Yung, supra note 8 , at 42 .

78. Dan M. Kahan, Gentle Nudges vs. Hard Shoves: Solving the Sticky Norms Problem, 67 U. CHI. L. REV. 607, 607 (2000). In introducing the "sticky norms" problem, Professor Dan M. Kahan notes the following:

To change the behavior of men (and women) who have internalized the norm that "no sometimes means yes," some states have modified their rape laws either to dispense with the common law element of force or to eliminate the "reasonable mistake of fact" defense with respect to consent. Empirical studies suggest, however, that such reforms have little effect on juries, which continue to treat verbal resistance as equivocal evidence of nonconsent, or on prosecutors, who remain reluctant to press charges unless the victim physically resisted the man's advances. 
describes this generally as the "sticky norms problem."79 "This problem occurs when the prevalence of a social norm makes decision[-]makers reluctant to carry out a law intended to change that norm." condemns a behavior significantly more severely than the typical decision maker-police officers, prosecutors, judges, and juries-this is a "hard shove." ${ }^{, 1}$ As a result, "the decision[-]maker's personal aversion to condemning too severely will dominate her inclination to enforce the law, and she will balk." ${ }^{, 2}$ Certain rape-by-nonphysical-coercion statutes, particularly those that criminalize rape by nonphysical coercion equally with rape involving physical force, may have represented "hard shoves" when they were enacted and may continue to be "hard shoves" today.

In contrast, when the law is a "gentle nudge" and only goes slightly beyond the typical decision-maker's norms, the decision-maker will be more likely to enforce the law as "her desire to discharge her civic duties will override her reluctance to condemn." 83 Further, enforcement by decisionmakers results in a feedback effect of social influence-as people perceive similarly situated people behaving in the same way, they are more likely to behave in that way as well. ${ }^{84}$

All of these factors - lack of clarity in laws that criminalize nonphysical coercion, overall under-enforcement of rape laws, and existing rape by nonphysical coercion laws potentially representing "hard shoves"-likely contribute to the current status of rape by nonphysical coercion laws. Understanding these factors and analyzing current laws can help to inform efforts to effectively reform existing laws and establish new laws.

\section{Proposed Alternatives}

In response to the existing but ineffective rape-by-nonphysical-coercion

Id.

79. Id.

80. Id.

81. Id. at 608 .

82. $I d$

83. $I d$.

84. Id. at 615. The feedback effects of social influence can either reinforce or diminish the likelihood of a specific behavior. Behaviors are reinforced when "a relatively large group of likesituated persons are engaging in a certain form of behavior," making it more likely others will also engage in the behavior, which then has the effect of increasing the overall size of the group and so on. Id. Behaviors are diminished "when an individual perceives that the group of individuals engaging in a behavior is relatively small," making it less likely a person will engage in the behavior, which then has the effect of reducing the overall size of the group and so on. Id. at 61516. 
statutes in some states and the lack of statutes in other states, scholars have presented several alternatives. These alternatives include: (1) expanding existing extortion statutes to include sex acts; ${ }^{85}$ (2) creating new rape-bynonphysical-coercion statutes modeled after existing extortion statutes ${ }^{86}$ (3) incorporating contract-law principles-including duress, undue influence, and unconscionability - into rape statutes, ${ }^{87}$ and (4) distinguishing between legitimate means to obtain sex and lawful offers versus illegitimate means and unlawful threats. ${ }^{88}$

\section{a. Expand Existing Extortion Statutes}

Professor Donald A. Dripps proposes a commodity theory to understand rape - in which sex or sexual cooperation is a commodity and rape is the theft of that commodity. ${ }^{89}$ Theft of sex occurs when sex is taken as a result of physical violence as well as in situations where sex is taken as a result of "pressures to cause sexual cooperation, short of violence"- the latter being "sexual expropriation." 90 While both would be criminal, sexual expropriation would carry lighter penalties than theft of sex involving physical violence. ${ }^{91}$ Specifically, Professor Dripps notes that "[sexual] [e]xtortion can be covered simply by amending the extortion statutes to include sex among the things it is criminal to obtain by unlawful threat." ${ }^{\text {"9 }}$

85. See, e.g., Dripps, supra note 7, at 1802.

86. See, e.g., MPC DRAFT, supra note $1, \S 213.4(1)$ (a) cmt., at 75.

87. See, e.g., Ann T. Spence, Note, A Contract Reading of Rape Law: Redefining Force to Include Coercion, 37 COLUM. J.L. \& Soc. PROBS. 57, 57 (2003).

88. See, e.g., SChUlhofer, Unwanted SeX, supra note 14, at 119-21 (discussing the difference between threats and offers, both legally and philosophically).

89. See Dripps, supra note 7, at 1786 ("According to the commodity theory, sexual cooperation is a service much like any other, which individuals have a right to offer for compensation, or not, as they choose.").

90. See id. at 1799-1800 (arguing that under "a rational criminal law of sex" nonviolent, coercive pressures to cause sexual cooperation should be punished, but not as harshly as situations that involve physical violence).

91. Id. Specifically, Professor Dripps includes a model statute under which "Sexually Motivated Assault" would carry the same sentence as aggravated assault, "Aggravated Sexually Motivated Assault" would carry the same sentence as rape, and "Sexual Expropriation" would be "punishable by a maximum prison sentence of one year and one day." Id. at 1807.

92. Id. at 1802 . 


\section{b. Create New Rape by Nonphysical Coercion Statutes Based on Extortion Statutes}

Similarly, the drafters of the proposed revisions to the Model Penal Code (MPC) on sexual assault and related offenses look to existing extortion and coercion statutes to define rape by nonphysical coercion. ${ }^{93}$ The draft MPC, however, goes beyond expanding existing extortion statutes to include sex. Rather, section 214.3 creates two new crimes: sexual penetration by coercion and sexual penetration by exploitation. ${ }^{94}$ Sexual penetration by coercion specifies contexts in which affirmative consent is deemed coerced and ineffective because it was obtained using nonviolent but impermissible means. ${ }^{95}$ Specifically, an individual is guilty of sexual penetration by coercion - a third-degree felony punishable by up to ten years in prison ${ }^{96}$ if:

[An individual] engages in an act of sexual penetration with another person and

(a) obtains that person's consent by threatening to:

(i) accuse anyone of a criminal offense or of a failure to comply with immigration regulations; or

(ii) expose any information tending to impair the credit or business repute of any person; or

(iii) take or withhold action in an official capacity, whether public or private, or cause another person to take or withhold action in an official capacity, whether public or private; or

93. See MPC DRAFT, supra note $1, \S 213.4$ (1)(a) cmt., at 75 (“Section 213.4(1)(a) . . . adopts as the criteria for impermissible coercion the tests that have long been the measure of illegality in connection with monetary demands."). The American Law Institute is in the process of updating Article 213 of the Model Penal Code-Sexual Assault and Related Offenses. Model PenAL CodE: SeXual Assault and Related OfFenses xv (Am. LAW Inst., Tentative Draft No. 1, 2014) [hereinafter MPC TENTATIVE DRAFT], http://jpp.whs.mil/Public/docs/03_Topic-Areas/02Article_120/20140807/03_ProposedRevision_MPC213_Excerpt_201405.pdf. The comprehensive revision project, which includes completely rewriting Article 213, began in 2012 and is ongoing. Id. As noted by the reporters preparing the updated provisions: "The social, cultural, and legal changes that have occurred since the [American Law] Institute's approval of the 1962 Code have rendered its provisions outdated, and they have been the subject of extensive scholarly criticism." MPC DRAFT, supra note 1 , introductory note, at 24 . As a result, the drafts include significant changes, such as the addition of section 213.4-Sexual Penetration by Coercion or Exploitation. See id. § 213.4, at 6970. Though the drafts incorporate changes based on criticisms of the 1962 Code, the drafts have also been subject to criticism. See infra notes 222-23 and accompanying text.

94. MPC DRAFT, supra note $1, \S 213.4$, at 69-70.

95. Id. § 213.4(1) cmt., at 70 .

96. Id. § 213.4(1), at 69; MPC TENTATIVE DRAFT, supra note 93, at xviii. 
(iv) inflict any substantial economic or financial harm that would not benefit the actor[. $]^{97}$

Sexual penetration by exploitation - a fourth-degree felony punishable by up to five years in prison ${ }^{98}$ - criminalizes sexual penetration in certain circumstances even if there is no threat. ${ }^{99}$ A discussion of this offense is outside the scope of this Comment, but given the similarities with sexual penetration by coercion, a brief summary is warranted. Under section 214.3(2), sexual penetration is prohibited between: (1) a mental-health professional and a current patient or (2) an attorney and a client, if the attorney is representing the client in a domestic-relations or criminal matter. ${ }^{100}$ In addition, sexual penetration is criminalized in the following instances of deception: (1) falsely representing that the act is a medically necessary treatment or (2) falsely causing the other person to believe that "he or she is someone with whom such person has been sexually intimate",101 (e.g., "when the imposter is an identical twin, when the victim is half-asleep in a darkened room, or when the victim, unclothed and in bed, is approached by the imposter from behind"102).

97. MPC DRAFT, supra note $1, \S 213.4(1)$, at 69.

98. Id. § 213.4(2), at 69; MPC TENTATIVE DRAFT, supra note 93, at xviii.

99. MPC DRAFT, supra note $1, \S 213.4(2) \mathrm{cmt}$., at 86 . Specifically, sexual penetration by exploitation is defined as follows:

An actor is guilty of Sexual Penetration by Exploitation... if he or she knowingly or recklessly engages in an act of sexual penetration with another person and the actor:

(a) is engaged in providing professional treatment, assessment, or counseling for a mental or emotional illness, symptom, or condition of such person over a period concurrent with or substantially contemporaneous with the time when the act of sexual penetration occurs, regardless of the location where such act of sexual penetration occurs and regardless of whether the actor is formally licensed to provide such treatment; or

(b) is a lawyer who is representing the other person in a domestic-relations matter or is representing the other person as a defense attorney in a criminal matter, the sexual penetration occurs during the course of the representation, and a consensual sexual relationship between the parties did not predate the lawyer-client relationship; or

(c) represents that the act of sexual penetration is for purposes of medical treatment or that such person is in danger of physical injury or illness which the act of sexual penetration may serve to mitigate or prevent; or

(d) knowingly leads such person to believe falsely that he or she is someone with whom such person has been sexually intimate. Id. § 213.4(2), at 69-70.

100. Id. § 213.4(2)(a)-(b), at 69 .

101. Id. $\S 213.4(2)(\mathrm{c})-(\mathrm{d})$, at $69-70$.

102. Id. $\S 213.4(2) \mathrm{cmt}$., at 107 (footnotes omitted). 


\section{c. Apply Contract Doctrines to Rape Law}

Ann T. Spence takes a different approach - using the contract doctrines of duress, undue influence, and unconscionability to expand the definition of force in rape and criminalize nonphysical coercion. ${ }^{103}$ Spence notes: "[J]ust as there is no bright-line rule that distinguishes between contracts and unlawfully coerced agreements, there is no bright-line rule that distinguishes between sex and rape." ${ }^{104}$ She argues, however, that contract doctrines can be used to "distinguish[] between permissible and impermissible means of persuasion." "105

In the Restatement (Second) of Contracts, a contract is voidable due to duress "[i]f a party's manifestation of assent is induced by an improper threat by the other party that leaves the victim no reasonable alternative."106 The improper threat can be legal in nature - such as threatening a crime or tort-or economic in nature. ${ }^{107}$ However, in order to constitute duress, the threat must leave the victim with no reasonable alternative. ${ }^{108}$

A contract can also be voidable due to undue influence. ${ }^{109}$ The Restatement (Second) of Contracts defines undue influence in part as "unfair persuasion of a party who is under the domination of the person exercising the persuasion." 110 Spence acknowledges that the concept of undue influence is implicitly recognized in statutes that prohibit sexual activity between an individual who is in a position of authority over another. ${ }^{111}$ "Position-of-authority" statutes, however, often specify certain relationships, rather than more broadly define the power imbalance. ${ }^{112}$

Finally, a court may refuse to enforce a contract if it was unconscionable when the parties entered into it. ${ }^{113}$ In evaluating whether a contract is unconscionable, courts consider if there was an imbalance in bargaining

\footnotetext{
103. Spence, supra note 87 , at 57.

104. Id. at 72 .

105. Id. at 60 .

106. ReStATEMENT (SECOND) OF CONTRACTS § 175(1) (AM. LAW. INST. 1981).

107. Spence, supra note 87, at 80; see also RESTATEMENT (SECOND) OF CONTRACTS $§ 176$ (describing when a threat is improper).

108. Spence, supra note 87 , at 80.

109. Id. at 84 .

110. RESTATEMENT (SECOND) OF CONTRACTS § 177(1).

111. Spence, supra note 87 , at 84 .

112. Id. The term position-of-authority statute is used by Professors Decker and Baroni. Decker \& Baroni, supra note 38, at 1126-27. Almost all states have some type of position-ofauthority statute. Id. at 1127 .

113. RESTATEMENT (SECOND) OF CONTRACTS § 208.
} 
power that was taken advantage of to create an unfair agreement. ${ }^{114}$ Spence proposes that the unconscionability principle could similarly be applied in rape cases "to prevent oppression." 115

\section{d. Distinguish Between Lawful Offers and Unlawful Threats}

Professor Stephen J. Schulhofer distinguishes between an offer-"a proposal that contemplates making the person better off, in return for her taking the action requested"-and a threat-" "a proposal to make a person worse off than she has a right to be."116 The critical premise is that every person is entitled to a "set of rights and expectations." impermissible and coercive because "it proposes to take away from [a person] something [she is] rightfully entitled to claim."118

Professor Schulhofer acknowledges that a person's specific scope of rights are not only ambiguously defined but subject to change. ${ }^{119}$ He argues, however, this framework is beneficial in analyzing the legitimacy or illegitimacy of different pressures. ${ }^{120}$

\section{State v. Brooks}

In Brooks, the Kansas Supreme Court took an approach different from any of the existing statutes and proposed alternatives. Under section 215503(a)(1)(A) rape is defined as "[k]nowingly engaging in sexual intercourse with a victim who does not consent to the sexual intercourse ... [w] hen the victim is overcome by force or fear." ${ }^{, 21}$ In Brooks, the court held that "or fear" does not just include fear of force, but rather "fear within the definition of rape is a highly subjective concept that does not lend itself to definition as a matter of law." 122 In this case, the defendant was guilty of

114. Spence, supra note 87 , at 88 .

115. Id. at 88-89 (quoting Deborah Zalesne, The Intersection of Socioeconomic Class and Gender in Hostile Housing Environment Claims Under Title VIII: Who is the Reasonable Person?, 38 B.C. L. REV. 861, 894 (1997)).

116. SCHULHOFER, UNWANTED SEX, supra note 14, at 120.

117. Id.

118. Id

119. Id.

120. See id. at 120-24 (applying the proposed framework to determine that a boyfriend telling his girlfriend that he will break up with her unless they have sex is not a threat as "the young man's demand for sex in the dating situation would not take from his girlfriend any right she is—or should be-entitled to hold").

121. KAn. Stat. AnN. § 21-5503(a)(1)(A) (Supp. 2015).

122. State v. Brooks, 317 P.3d 54, 63 (Kan. 2014) (emphasis added) (quoting State v. Tully, 262 
rape when the victim was overcome by fear due to threats to expose the victim's affair with a married coworker. ${ }^{123}$

\section{The Facts}

George James Brooks, III ("Brooks") and J.P. were married for nearly ten years before they separated in May 2005 and divorced ten months later. ${ }^{124}$ Several months following their divorce, Brooks called J.P. to tell her that he had copies of emails between J.P. and her married coworker showing that the two had an affair. ${ }^{125}$ Brooks informed J.P. that "he would be coming over to her house for sex that evening." 126

Brooks arrived at J.P.'s house that evening with the copies of the emails and threatened to give them to her employer and her coworker's wife unless she had sex with him. ${ }^{127}$ After putting their young daughter to bed, J.P. tried to reason with Brooks, reminding him that what he was doing was wrong and they were divorced. ${ }^{128}$ She made clear to Brooks that she did not want to have sex with him, saying: "I don't want to do this. ... This is against my will." 129 Brooks, however, responded that "he didn't have a problem with that." 130

Brooks then told J.P. to take off her underwear, and when she hesitated, he became agitated. ${ }^{131}$ J.P. complied and Brooks proceeded to have sex with J.P. while she sat in a chair with her eyes closed and hands over her face. ${ }^{132}$ After Brooks was done, he informed J.P. that this had been a "test" and he would back on Friday. ${ }^{133}$

The following day, J.P. told her attorney and her counselor what had happened and they encouraged her to tell the police. ${ }^{134}$ The police gave J.P. a recorder, and J.P. taped several calls with Brooks during which he demanded money and sex. ${ }^{135}$ J.P. arranged to meet with Brooks on May

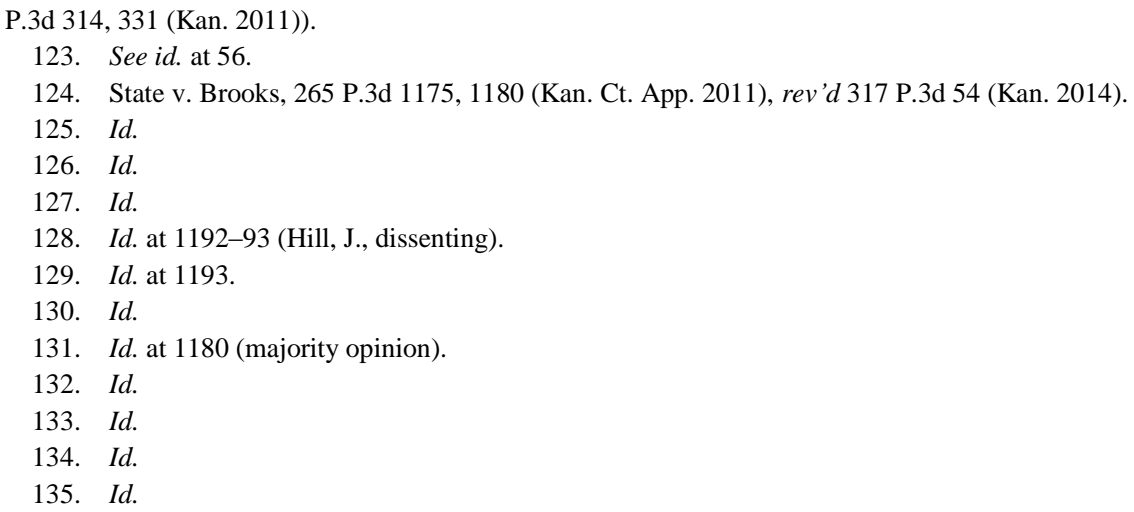


12. ${ }^{136}$ When Brooks arrived at J.P.'s house, the police arrested him. ${ }^{137}$

\section{The Trial and Kansas Court of Appeals Opinions}

A jury found Brooks guilty of one count of rape, two counts of blackmail, and one count of breach of privacy. ${ }^{138}$ The court sentenced him to consecutive sentences of 155 months for the rape conviction and 12 months for each blackmail conviction, totaling 179 months in prison. ${ }^{139}$

Specifically, the jury found Brooks guilty of rape for engaging in "[s]exual intercourse with a person who does not consent to the sexual intercourse ... [w] hen the victim is overcome by force or fear ." the trial, J.P. testified that the sex was nonconsensual, and she only had sex with Brooks because he threatened to expose the affair with her coworker. ${ }^{141}$ J.P. did not think Brooks would physically hurt her if she refused, but she believed he would follow through with his threat. ${ }^{142}$ While J.P. did not believe she would be fired or suffer direct adverse employment consequences as a result of the affair being exposed, she believed it would taint the workplace environment. ${ }^{143}$

Brooks appealed the rape and breach of privacy convictions. ${ }^{144}$ With considerable reluctance, the Kansas Court of Appeals reversed these convictions. ${ }^{145}$ The court noted that while the punishment for blackmail convictions "seems entirely too lenient when the victim has been coerced to submit to a violation of her bodily integrity and to a particular act that when

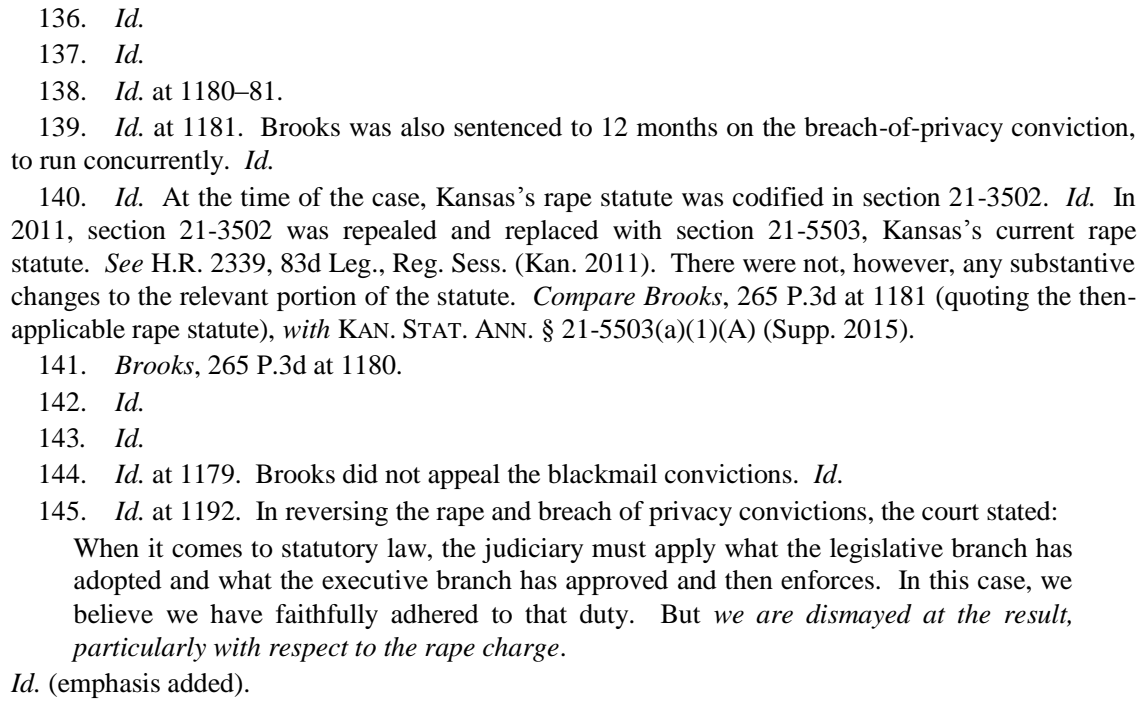

140. Id. At the time of the case, Kansas's rape statute was codified in section 21-3502. Id. In 2011, section 21-3502 was repealed and replaced with section 21-5503, Kansas's current rape statute. See H.R. 2339, 83d Leg., Reg. Sess. (Kan. 2011). There were not, however, any substantive changes to the relevant portion of the statute. Compare Brooks, 265 P.3d at 1181 (quoting the thenapplicable rape statute), with KAN. STAT. ANN. § 21-5503(a)(1)(A) (Supp. 2015).

141. Brooks, 265 P.3d at 1180.

142. Id

143. Id.

144. Id. at 1179. Brooks did not appeal the blackmail convictions. Id.

145. Id. at 1192. In reversing the rape and breach of privacy convictions, the court stated: When it comes to statutory law, the judiciary must apply what the legislative branch has adopted and what the executive branch has approved and then enforces. In this case, we believe we have faithfully adhered to that duty. But we are dismayed at the result, particularly with respect to the rape charge.

Id. (emphasis added). 
compelled constitutes nothing less than defilement," Brooks's conduct did not fit the statutory definition of rape. ${ }^{146}$

In interpreting "fear" in the rape statute, the Kansas Court of Appeals first held that the use of "force or fear" in the statute constitutes a single means of committing rape. ${ }^{147}$ As a result, the evidence only needs to support the victim being overcome by either force or fear, not both. ${ }^{148}$ However, because "force or fear" constitutes a single means of committing rape, the court then held that there must be some commonality between the type of force and type of fear contemplated in the statute. ${ }^{149}$ Thus, the court held fear as used in the rape statute means "fear resulting from the use or threat to use force against the victim, another person, or property."

The court acknowledged that J.P.'s fear of having the affair exposed and being subject to scorn, ridicule, and embarrassment constituted a legitimate and rational emotional fear and was an invasion of J.P.'s privacy with a potentially substantial impact. ${ }^{151}$ However, due to likely an "inadvertent omission" by the legislature, this type of fear did not constitute the type of fear included in the rape statute. ${ }^{152}$ As a result, the court reversed the rape conviction. ${ }^{153}$

In concluding its opinion, the Kansas Court of Appeals called upon the legislature to provide a solution going forward, ${ }^{154}$ noting that: "The outcome leaves J.P. without a full measure of justice for what Brooks did to her in this case. And the people of this state have neither adequate penal sanctions to invoke in the next case nor sufficient deterrent punishments to prevent

146. Id. at 1182. The court also emphasized that while Brooks's conduct clearly fit the blackmail statute, it is unlikely the legislature anticipated situations like the one in this case when adopting the blackmail statute. $I d$. The court noted the relatively lenient punishment under the blackmail statute as support for this belief. Id. "Blackmail is a severity level 7 nonperson felony. As felonies go, that is comparatively mild. For a defendant without any significant criminal history, as Brooks, the guidelines punishment would be 11 to 13 months in prison but with a presumption of probation rather than incarceration." Id.

147. Id. at 1184. The court explained "force or fear" could either indicate a single means of committing rape-like the court held—or alterative means. Id. at 1182.

148. Id. at 1182. Conversely, for alterative means crimes, if "the prosecution declines to elect one or the other, resulting in a jury instruction on both, the evidence must be sufficient to support each." Id.

149. See id. at 1184 (explaining if there was no connection between the two words, "force and fear would amount to alternative means of committing rape").

150. See State v. Brooks, 317 P.3d 54, 63 (Kan. 2014) (summarizing the interpretation of fear by the Kansas Court of Appeals).

151. Brooks, 265 P.3d at 1186

152. Id

153. Id. at 1192 .

154. See id. at 1186, 1192 (explaining that the result commanded by the statute may have been a drafting error instead of a policy choice, and finding fault with the Kansas Criminal Code). 
what would be the case after that." 155

\section{The Kansas Supreme Court Opinion}

In 2014, the Kansas Supreme Court provided a solution, reversing the Kansas Court of Appeals and affirming Brooks's rape conviction. ${ }^{156}$ The Kansas Supreme Court agreed that force or fear is a single means of committing rape. ${ }^{157}$ The terms describing the elements of a single-means crime, however, do not need to have interconnected definitions. ${ }^{158}$ Rather, the terms can have significantly different meanings. ${ }^{159}$ Fear could have a meaning entirely independent from force - if that was what the legislature intended. ${ }^{160}$

Without the constraint of needing a commonality between fear and force, the court analyzed the rape statute, emphasizing that if the intent of the legislature can be ascertained, the intent governs. ${ }^{161}$ If the plain text of a statute is clear and unambiguous, the court should not use cannons of statutory construction or look to legislative history to try to determine an underlying intent. ${ }^{162}$ Instead, the court should apply ordinary meanings of the common words and not read anything into the statute that is not explicitly stated. ${ }^{163}$

The court contrasted the plain text of section 21-3502-"force or fear"- with Pennsylvania's rape statute, which specifically qualifies the type of threat, requiring intercourse "“by forcible compulsion' or 'threat of forcible compulsion that would prevent resistance by a person of reasonable resolution." "164 The Kansas statute does not qualify the type of fear required, and thus, the court would not read in any unstated qualifications to its definition. ${ }^{165}$

155. Id. at 1192.

156. State v. Brooks, 317 P.3d 54, 67 (Kan. 2014).

157. Id. at 56.

158. See id. at 64-65 ("Our recent alternative means caselaw [sic] clearly shows that the legislature can use terms with vastly different meanings to describe a single material element or factual circumstance that would prove the crime.").

159. Id.

160. See id.

161. Id. at 63-65.

162. Id. at 63 .

163. Id.

164. Id. at 64 (quoting State v. Borthwick, 880 P.2d 1261, 1270 (Kan. 1994)); see also 18 PA. CONS. STAT. $\$ 3121$ (Supp. 2014).

165. See Brooks, 317 P.3d at 64 (noting that the court of appeals had read language into the statute, violating well-known rules of statutory interpretation). 
Referring to its analysis in State v. Tully ${ }^{166}$ and State v. Borthwick, ${ }^{167}$ the court explained that "fear within the definition of rape is a highly subjective concept that does not lend itself to a definition as a matter of law." "Th8 Thus, as long as the victim testifies that he or she was overcome by fear and the "testimony is not "so incredible as to defy belief," the fact finder should determine whether the overcome-by-fear element is met. ${ }^{169}$ The jury, however, can consider the reasonableness of the fear when determining whether to believe the testimony. ${ }^{170}$

Reviewing the evidence presented at trial, the court held that there was sufficient evidence for a reasonable jury to find Brooks guilty beyond a reasonable doubt on the basis that J.P. was overcome by fear. ${ }^{171}$ In addition to her testimony, J.P.'s actions of covering her face and closing her eyes while Brooks had sex with her supported the inference that J.P. was overcome by fear. ${ }^{172}$ As a result, the Kansas Supreme Court reversed the decision of the Kansas Court of Appeals and affirmed Brooks's rape conviction. ${ }^{173}$

\section{ANALYSIS}

In its outcome-motivated analysis, the Kansas Supreme Court failed to provide a clear standard that can be applied going forward. Brooks's conduct was reprehensible and appropriately criminalized. However, the standard, or rather lack of a standard, that fear is "highly subjective"174 and as long as the victim's testimony is not "'so incredible as to defy belief,' there is sufficient evidence to present the ultimate determination to the factfinder" 175 could lead to a lack of predictable results and an overcriminalization of conduct.

Part A of this section analyzes the court's interpretation of section 215503 , focusing on why the highly subjective standard is problematic. Part B

\footnotetext{
166. State v. Tully, 262 P.3d 314 (Kan. 2011). See infra note 180 for a summary of the Tully case.

167. State v. Borthwick, 880 P.2d 1261 (Kan. 1994). See infra note 180 for a summary of the Borthwick case.

168. Brooks, 317 P.3d at 63 (emphasis added) (quoting Tully, 262 P.3d at 331).

169. Id. at 64 (quoting Borthwick, 880 P.2d at 1271, 1279).

170. Id.

171. Id. at 66.

172. Id. at $65-66$

173. Id. at 67.

174. Id. at 63 (quoting State v. Tully, 262 P.3d 314, 331 (Kan. 2011)).

175. Id. at 64 (quoting State v. Borthwick, 880 P.2d 1261, 1279 (Kan. 1994)).
} 
argues nonphysical coercion should be criminalized in certain circumstances, but other existing statutes and proposed alternatives are also problematic. Part $\mathrm{C}$ outlines and applies an alternative based on a blended, incremental approach to better strike the balance between criminalizing impermissible coercion, while also recognizing the existence permissible persuasion.

\section{A. The Unworkable Standard of State v. Brooks}

While this Comment focuses on why the highly subjective standard is problematic - regardless of whether the Kansas Supreme Court correctly interpreted section 21-5503-a brief analysis of the court's statutory interpretation is warranted. Part 1 of this section discusses the Kansas Supreme Court's analysis of section 21-5503, followed by Part 2, which analyzes the resulting highly subjective standard.

\section{Statutory Analysis}

Under the statutory interpretation framework outlined by the Kansas Supreme Court, if the plain text of a statute is clear and unambiguous, the court should not use cannons of statutory construction or look to legislative history to determine an underlying intent. ${ }^{176}$ Consistent with this approach, the Kansas Supreme Court concluded that the plain text of section 21-5503 is clear and unambiguous, so therefore, further statutory interpretation was unnecessary. ${ }^{177}$ Further, the Kansas Supreme Court "refuse[d] to qualify the term fear and instead note[d] that fear is an inherently subjective concept because... '[w] hat renders one person immobilized by fear may not frighten another at all.",178

Whether the plain text of the statute is clear and unambiguous is debatable. If the text of the statute is clear and unambiguous, one might expect other cases similar to Brooks to have been brought under the statute. The "force or fear" language has been in the statute since 1969. ${ }^{179}$ However, neither the Kansas Court of Appeals nor the Kansas Supreme Court cited to another case where a defendant was convicted for rape when the victim was overcome by fear due to threats even remotely similar to those made by

\footnotetext{
176. Id.

177. See id. at 64-65 (holding that fear is highly subjective based on the statute's plain language and without looking to the legislative history).

178. Id. at 65 (quoting Borthwick, 880 P.2d at 1270).

179. See infra notes $181-84$ and accompanying text.
} 
Brooks. $^{180}$

Assuming, however, that the plain text is ambiguous, there is little legislative history to assist in interpreting the force or fear language. The language was added in 1969 as part of a comprehensive update to Kansas's criminal law. ${ }^{181}$ The existing 1929 rape statute-defining rape as "carnally and unlawfully knowing any female person under the age of eighteen years" or "forcibly ravishing any female person"-was replaced with section 21$3501{ }^{182}$ Section 21-3501 defined rape as: "[T] he act of sexual intercourse committed by a man with a woman not his wife, and without her consent ... $[w]$ hen a woman's resistance is overcome by force or fear...."183 The legislature made several subsequent amendments-including removing the marital exemption and resistance requirement and making it genderneutral — but "force or fear" has remained. ${ }^{184}$

Ultimately, irrespective of whether the court correctly interpreted the statute, legislative reform is needed. Assuming the Kansas Supreme Court did not correctly interpret the statute, and the better interpretation was that of the Kansas Court of Appeals: fear is limited to "fear resulting from the use or threat to use force against the victim, another person, or property," 185 legislative reform is needed to expand the definition to criminalize

180. Instead, the Kansas Supreme Court primarily referred to Tully and Borthwick. See Brooks, 317 P.3d at 65 . Both of these cases are easily distinguished from Brooks. In Tully, the defendant, who was nineteen years old, was charged with raping A.C., who was fourteen years old and intoxicated. State v. Tully, 262 P.3d 314, 320 (Kan. 2011). The court ultimately reversed the convictions due to several procedural errors and remanded the case. Id. In reviewing the jury instructions, the court explained that "force or fear within the definition of rape is a highly subjective concept" and "the question of whether a victim is overcome is one of fact for the jury to decide." Id. at 331. The court ultimately held that the district court's jury instructions omitted key language on the element of force and were potentially confusing. Id. at 332. In Borthwick, the defendant was convicted of raping J.C., who had spastic hemiplegia cerebral palsy and could not walk without assistance or stand without support. Borthwick, 880 P.2d at 1264. The defendant laid J.C. down on the floor and, despite her repeatedly asking him to stop, digitally penetrated J.C. Id. "J.C. testified that she was afraid ... and that she felt powerless to stop [the assault]." Id. at 1269. The court discussed fear as well as force, and ultimately "conclude[d] that a rational factfinder could have concluded beyond a reasonable doubt that the sexual intercourse was nonconsensual and that the victim was overcome by force or fear." Id. at 1271.

181. See Kansas Judicial Council Bulletin, Proposed Kansas Criminal Code 6-8 (1968) (noting the objectives of the criminal law revisions, including "conform[ing] the law to the accepted standards and concepts of modern penal legislation" and "stat[ing] in clear, simple and understandable terms the elements of the prohibited acts").

182. See H.B. 172, 43rd Leg., Reg. Sess., 272 (Kan. 1929); S.B. 9, 63rd Leg., Reg. Sess., 456 (Kan. 1969).

183. S.B. 9, 63rd Leg., Reg. Sess., 456.

184. Compare id., with Kan. STAT. AnN. § 21-5503 (Supp. 2015).

185. Brooks, 317 P.3d at 64 (summarizing the interpretation of fear by the Kansas Court of Appeals). 
nonphysical coercion in certain circumstances. ${ }^{186}$ Similarly, if the Kansas Supreme Court correctly interpreted the statute, legislative reform is needed to clarify and narrow the circumstances in which nonphysical coercion is criminalized. The highly subjective standard set forth in Brooks is too broad and could lead to a lack of predictable results and an over-criminalization of conduct.

\section{An Unworkable Standard}

Consider the possibilities of behavior that could be criminal under the highly subjective standard if the victim was overcome by fear as a result of the threat. As noted in the commentary to the draft of the revised MPC on sexual assault and related offenses:

The range of potentially troublesome incentives and threats used to induce sexual submission is almost impossibly broad and varied: a police officer's threat to arrest or offer not to make a justifiable arrest; a job supervisor's intention to fire an employee, block a promotion, or expedite an undeserved promotion; a threat to expose another person's adultery, embezzlement, irregular immigration status, or sexual orientation; a wealthy person's threat to stop supporting a paramour; a person's threat to break off a dating relationship - the list is endless, and the criteria for distinguishing between legitimate exchange and impermissible compulsion are by no means uniformly agreed upon. ${ }^{187}$

Under the "highly subjective" standard, a defendant could be guilty of rape if the victim was overcome by fear due to any of these threats. Provided the victim's testimony is "not 'so incredible as to defy belief,", it would ultimately be left to the fact finder to determine whether the victim was overcome by fear. ${ }^{188}$

"The reasonableness of a particular victim's fear may affect the jury's assessment of the victim's credibility in arriving at its verdict." "189 However, under Brooks, provided the jury believes the victim was overcome by fear, a defendant could be guilty of rape regardless of how objectively reasonable the fear was or was not. Some of these examples may be extreme, such as an individual's threat to end a dating relationship. Perhaps the fact finder would not believe a victim was overcome by fear due this type of threat, but

186. See supra Part III.C.I for a discussion of the circumstances in which nonphysical coercion should be criminalized under rape law.

187. MPC DRAFT, supra note $1, \S 213.4(1) \mathrm{cmt}$., at 70.

188. Brooks, 317 P.3d at 64 (quoting State v. Borthwick, 880 P.2d 1261, 1279 (Kan. 1994)).

189. Id. 
at what point does a person become overcome by fear? Can a person be overcome by fear from a threat to file for divorce and sue for child custody? Should idiosyncratic fears - that the threat-maker may or may not know of-be included? ${ }^{190}$ In Brooks, the Kansas Supreme Court notes that "[w] hat renders one person immobilized by fear may not frighten another at all." ${ }^{\prime 191}$ The highly subjective standard places no boundaries as to what type of threats could be criminal.

Further, the Brooks standard provides little guidance for the fact finder to determine at what point someone is overcome by fear. In her dissent, Justice Moritz agrees that J.P. feared that Brooks would expose the affair, but disagrees with the majority's holding that there was sufficient evidence that J.P. was overcome by fear. ${ }^{192}$ Justice Moritz equates being "overcome by fear" with being "immobilized or paralyzed" by fear. ${ }^{193}$ In his dissent, Justice Johnson agrees with Justice Moritz's definition of being "overcome by fear." 194

However, as noted by the majority, in their arguments, "i.e., how a rape victim should act, both of the dissents take on the role of a jury, weighing the evidence and passing on the credibility of J.P., something that is clearly improper on appellate review." ${ }^{~} 195$ The majority then concludes there was sufficient evidence that J.P. was overcome by fear-"i.e., her fear got the better of her; her fear affected or influenced her so strongly as to make her physically helpless; her fear overpowered, conquered, and subdued her."196

Defining how a rape victim "should" act would be unwise. Numerous studies show the responses of rape victims are varied. ${ }^{197}$ However, as demonstrated by the majority opinion and both dissents in Brooks, this question inevitably arises when examining the facts to determine if there was sufficient evidence to support a finding that the victim was overcome by fear.

190. This point is noted by Justice Johnson in his dissent in Brooks: "[M]aking the overcomeby-fear element a purely subjective determination, such that a defendant might not have known of the existence or degree of his sexual partner's phobia(s), could raise due process concerns." Id. at 67 (Johnson, J., dissenting).

191. Id. at 64 (majority opinion) (quoting Borthwick, 880 P.2d at 1277).

192. Id. at 68 (Moritz, J., dissenting).

193. Id.

194. See id. at 67-68 (Johnson, J., dissenting).

195. Id. at 66-67 (majority opinion).

196. Id. at 67 (citing WebSTER's THIRD NEW INTERNATIONAL DiCTIONARY 1607 (1993)).

197. See generally PATRICIA L. FANFLIK, NAT'L Dist. ATtORNEYS ASS'N, Victim RESPONSES to SeXual Assault: Counterintuitive OR Simply Adaptive? (2007), http://www.ndaa.org/pdf/pub_victim_responses_sexual_assault.pdf (discussing victims' varying reactions to rape). 
Ignoring for a moment the question of whether any, some, or all of the types of threats described at the beginning of this section should be criminalized, and if so, what the punishment should be, the Brooks highly subjective standard remains problematic. Rape is a seriously-punished crime. In Kansas, rape when the victim is overcome by force or fear is a level one person felony. ${ }^{198}$ Thus, a defendant with no prior criminal history convicted of rape would be subject to between 147 (mitigated sentence) and 165 (aggregated sentence) months in prison under Kansas's sentencing guidelines. ${ }^{199}$ The sentencing court would have discretion in assigning the sentence within the range, with the grid listing a standard sentence of 155 months. ${ }^{200}$ Thus, not only does the highly subjective standard fail to provide a predictable standard as to when behavior would or would not be criminal, but if it is criminal, the punishment is severe.

\section{B. Criminalizing Rape by Nonphysical Coercion and Analyzing Existing Alternatives}

An analysis of Brooks, however, cannot ignore the question of whether nonphysical coercion should be criminalized. Part 1 of this section argues rape by nonphysical coercion should be criminalized in certain circumstances, but as discussed in Part 2, similar to the highly subjective standard, existing alternatives also present their own drawbacks.

\section{Criminalizing Rape by Nonphysical Coercion}

Legislatures, courts, and commentators will inevitably disagree over whether and to what extent certain behaviors should be criminal. ${ }^{201}$ Generally, however, many commentators agree nonphysical coercion should

\footnotetext{
198. KAN. STAT. ANN. § 21-5503(b).

199. Id. § 21-6804(a). Kansas's sentencing guidelines grid takes into account both the severity of the crime (vertical axis) and the criminal history of the defendant (horizontal axis). Id. § 216804(a), (c). Crime severity ranges from level one to ten, and criminal history ranges from one misdemeanor or no criminal history to three or more person felonies. Id. For each combination of severity level and criminal history, the grid provides a sentencing range. Although the court has discretion to sentence anywhere in the range, the statute recommends using the center of the range in the usual case. Id. § 21-6408(e)(1)

200. Id.

201. For example, there was disagreement at both levels of appellate review in Brooks. At the Kansas Court of Appeals, Judge Hill authored a dissenting opinion. State v. Brooks, 265 P.3d 1175, 1192 (Kan. Ct. App. 2011) (Hill, J., dissenting), rev'd 317 P.3d 54 (Kan. 2014). At the Kansas Supreme Court, two justices authored separate dissenting opinions. State v. Brooks, 317 P.3d 54, 67-68 (Kan. 2014) (Johnson, J., dissenting); id. at 68 (Moritz, J., dissenting).
} 
be criminalized in at least certain circumstances. ${ }^{202}$ As noted in the commentary to the draft MPC, "American law has long since moved beyond the uniform view in the early 20th century that physical harm and threats of violence [are] the only impermissible means to secure submission to a sexual demand." ${ }^{203}$ This view is also consistent with the underlying fundamental values for treating rape as distinct crime-sexual autonomy, harm, gender, and terror. ${ }^{204}$

The right to "choose freely whether and when to be sexually intimate with another person" 205 should include more than just freedom from unwanted physically forced sex. Numerous other areas of the law recognize intrusions on autonomy beyond just physical force. Extortion or blackmail statutes under criminal law define impermissible threats in connection with monetary demands. ${ }^{206}$ In contract law, contacts are voidable when they are a result of impermissible nonphysical coercion and violate an individual's autonomy under the doctrines of duress, undue influence, and unconscionability. ${ }^{207}$ Intrusions on an individual's sexual autonomy should similarly be recognized as unlawful and penalized as such.

Further, the fundamentals of sexual autonomy, harm, gender, and terror continue to apply to when considering rape by nonphysical coercion. In particular, social sanctions - one of the factors making the harm of rape unique - may be worse for a victim of rape by nonphysical coercion. Rape victims are already treated differently from victims of other crimes. ${ }^{208}$ The likelihood of being asked why you put yourself in a certain situation or why you were in a certain part of town is lower when you are reporting your wallet being stolen than being raped. ${ }^{209}$ When considering rape by nonphysical coercion, the question of "why did you not just say no and

202. See, e.g., Falk, Rape, supra note 59, at 47 ("[T] he critical question is no longer if rape law should prohibit sexual conduct secured by fraud or coercion, but rather when (or under what circumstances) such behavior merits criminal sanction."); Dripps, supra note 7, at 1799 ("The second, and far more difficult, step toward a rational criminal law of sex would be to define and grade those pressures to cause sexual cooperation, short of violence, that deserve to be punished as crimes."); Decker \& Baroni, supra note 38, at 1168 ("Coercion in any form or taking advantage of one's position of authority to achieve sex must be outlawed everywhere.”).

203. MPC DRAFT, supra note $1, \S 213.4(1) \mathrm{cmt}$., at 70.

204. See supra notes 17-25 and accompanying text.

205. MPC DRAFT, supra note 1 , introductory note, at 16.

206. See, e.g., Model PENAL CODE $§ 223.4$ (Proposed Official Draft 1962) (criminalizing theft by extortion if a person "purposely obtains property of another by threatening" one of seven enumerated items).

207. See Spence, supra note 87, at 57; see also supra notes $103-15$ and accompanying text.

208. Yung, supra note 8, at 21-22.

209. See id. 
refuse" will surely be asked. The victim will then be forced to explain why he or she did not "just say no and refuse" - a question that would less likely be asked when someone has been raped by physical force.

A lack of physical force or threats of force should not make nonconsensual sex legal. Nonphysical coercion should be criminalized in certain circumstances. The challenge, however, is defining those certain circumstances.

\section{Existing Alternatives and Other Proposed Approaches}

As discussed in Part.III.A.2, the highly subjective standard of Brooks leaves Kansas with a poorly defined standard that will lead to unpredictable results. Further, neither the approaches taken in other states that criminalize rape by nonphysical coercion ${ }^{210}$ nor the alternatives suggested by scholars ${ }^{211}$ offer independent solutions.

A key similarity across all the approaches taken in states that criminalize rape by nonphysical coercion is the lack of case law. ${ }^{212}$ This probably reflects either a lack of prosecutions or prosecutions but a lack of convictions. ${ }^{213}$ As discussed in Part II.B.1, the lack of effective enforcement is likely a function of multiple factors-lack of clarity in the laws of states that criminalize nonphysical coercion, overall under-enforcement of rape laws, and existing rape by nonphysical coercion laws potentially representing "hard shoves." 214 While the overall under-enforcement of rape laws goes beyond just rape by nonphysical coercion laws, the other two explanations can be specifically taken into account when analyzing how to best define the circumstances in which nonphysical coercion should be illegal. The existing laws can also provide examples - both of what not to do as well as approaches that may be beneficial.

Just as some of the existing laws provide models for determining how best to set the parameters of rape by nonphysical coercion, so do the alternatives suggested by scholars. In leveraging the alternatives in defining a new approach, however, it is important to consider both the benefits and drawbacks of the various approaches.

Professor Dripps offers a simple approach of "amending the extortion statutes to include sex among the things it is criminal to obtain by unlawful

\footnotetext{
210. See supra Part II.B.1.

211. See supra Part II.B.2.

212. See supra notes $68-70$ and accompanying text.

213. See supra notes 71-73 and accompanying text.

214. See supra notes 74-84 and accompanying text.
} 
threat." 215 However, as noted by Professor Patricia J. Falk, it "makes no provision for the unique harm endemic to sexual offenses."216 Like including rape under a battery statute, simply expanding the scope of extortion statutes fails to recognize the fundamental values for treating rape as distinct crime. As aptly noted by the Kansas Court of Appeals, the punishment under the blackmail convictions -12 months for each conviction--"seems entirely too lenient when the victim has been coerced to submit to a violation of her bodily integrity and to a particular act that when compelled constitutes nothing less than defilement." 217

The sexual penetration by coercion offense in the draft MPC on sexual assault and related offenses provides a useful starting point, but it is both under- and over-inclusive. By narrowly defining the circumstances in which a threat is impermissibly coercive to threats to: (1) accuse someone of a crime or failure to comply with immigration regulations; (2) expose information to impair a person's credit or business reputation; (3) "take or withhold an action in an official capacity", ${ }^{218}$ or (4) "inflict any substantial economic or financial harm" ${ }^{, 219}$ a large portion of reprehensible behavior will remain legal.

Specifically, the drafters noted that expanding the second type of threats listed to include the following italicized language could be defended: "[T]hreats to expose 'any information, not intrinsic to or arising out of interaction between the actor and such other person, which would tend to subject any person to hatred, contempt or ridicule, or to impair the credit or business repute of any person." 220 The drafters, however, opted for the narrower approach - excluding the italicized language-because (1) the narrower approach already goes significantly beyond the circumstances in which most states currently criminalize sexual offenses; "(2) the potentially broad scope and vague content of criteria such as hatred, contempt, and ridicule in this context; and (3) the general preference for parsimony in situations where the need for criminal sanctions is unclear." 221

The narrower language selected by the drafters, however, also has the potential to be broad and over-inclusive. ${ }^{222}$ As noted in the May 12, 2015

\footnotetext{
215. Dripps, supra note 7, at 1802 .

216. Falk, Rape, supra note 59, at 174.

217. State v. Brooks, 265 P.3d 1175, 1182 (Kan. Ct. App. 2011), rev'd 317 P.3d 54 (Kan. 2014).

218. MPC DRAFT, supra note $1, \S 213.4(1)$ (a)(iii), at 69.

219. Id. § 213.4(1)(a)(iv), at 69 .

220. Id. $\S 213.4(1)$ (a) cmt., at 79-80.

221. Id. § 213.4(1)(a) cmt., at 80 .

222. The expansive scope of the proposed revised Article 213 and the potential for a broad over-
} 
memorandum signed by numerous American Law Institute members, "[t]he draft has no de minimis threshold for a 'threat' that is criminalized so long as the complainant claims that the 'threat' was the cause of the consent to sexual intercourse, thereby nullifying the coerced consent." ${ }^{223}$ For example, under section 213.4(1)(a)(ii) - the "narrower" language - threats to "expose any information tending to impair the credit or business repute of any person" are criminalized. ${ }^{224}$ This language is not qualified like section 213.4(1)(a)(iv), which criminalizes threats to "inflict any substantial economic or financial harm." 225 Under section 213.4(1)(a)(ii), if J.P. owned her own business and exposure of the affair would "tend to impair [her] ... business repute" - even in small way-Brooks's threat would be captured under the statute. ${ }^{226}$

Further, linking the coerciveness of a threat to other criminal offenses has the potential to result in odd outcomes. For example, in Kansas, adultery is a criminal offense. ${ }^{227}$ Under section 21-5511, it is class C misdemeanor to engage in "sexual intercourse ... with a person who is not married to the offender if ... [t] $]$ he offender is married ...."228 Thus, at least in Kansas, Brooks's conduct would be considered sexual penetration by coercion. However, in another state that does not criminalize adultery, Brooks's conduct would not be captured under the statute. The drafters even acknowledged this result, ${ }^{229}$ but offered no solution to address this outcome. Should whether an individual has committed sexual penetration by coercion turn on whether the state criminalizes adultery?

criminalization of conduct are key critiques of the drafts. See Memorandum from Undersigned ALI Members and Advisers on Revisions to Sexual Assault Provisions of the Model Penal Code 1 (May 12, 2015), http://downloads.mensactivism.org/ALIMemo20150512.pdf.

223. Id. at 6 . The memorandum provides the following hypothetical:

Suppose that Person A "threatens" to vote for the contestant not preferred by Person B, the sex partner of Person A, during the viewer voting phase of the television show "American Idol." Six months later, Person B files a criminal complaint alleging that this "threat" was the means by which Person A "obtains consent" to sexual intercourse with Person B. Person A is guilty of a ten-year felony because of this "threat" to "cause another person [the recorder of "American Idol" votes] to take or withhold action in an official capacity, whether public or private." Yes, that is an absurd result but this model statute intended for promulgation to the states invites this result as well as many others that would work to over[-]criminalize and over[-]incarcerate.

Id. (citation omitted).

224. MPC DRAFT, supra note $1, \S 213.4(1)$ (a)(ii), at 69 (emphasis added).

225. Id. § 213.4(1)(a)(iv), at 69 (emphasis added).

226. See id. \$213.4(1)(a)(ii), at 69.

227. Kan. STAT. ANN. § 21-5511 (Supp. 2015).

228. Id.

229. MPC DRAFT, supra note $1, \S 213.4(1) \mathrm{cmt}$., at $80 \mathrm{n} .247$. 
Finally, Spence's proposal of using contract law doctrines to expand the definition of force in rape and criminalize nonphysical coercion, ${ }^{230}$ as well as Professor Schulhofer's focus on distinguishing between lawful offers and unlawful threats, ${ }^{231}$ are both helpful in understanding and thinking about how to define when nonphysical coercion is criminal. Neither, however, clearly explains how to translate those approaches into specific statutory language.

\section{Creating a Better Approach}

There is not a single correct approach to criminalizing rape by nonphysical coercion. Ultimately, however, "[t]he law must choose, from among empirically imperfect standards, the one best able to guide behavior and minimize the cost of inevitable over- and under-inclusiveness. ${ }^{232}$ In defining a specific standard, it important to consider the advantages and disadvantages of potential approaches, analyze trade-offs offered by different options, and be aware of social norms implicitly reflected in any standard. Part 1 of this section describes an alternative to criminalizing rape by nonphysical coercion based on a blended, incremental approach to better strike the balance between criminalizing impermissible coercion, while recognizing the existence permissible persuasion. Part 2 illustrates how the approach would apply in different circumstances. Finally, Part 3 reflects on the advantages of the proposed approach, while also considering potential shortcomings.

\section{Defining a Blended, Incremental Approach}

This Comment proposes a blended, incremental approach to criminalizing rape by nonphysical coercion. The approach is blended because it draws from alternatives proposed by scholars and approaches taken by states that criminalize nonphysical coercion. The approach is incremental as does not criminalize all nonphysical coercion and grades rape by nonphysical coercion as a lesser offense than rape involving force. As a result, it hopefully represents a "gentle nudge" towards condemning this type of behavior rather than a "hard shove." 233

Specifically, this Comment proposes criminalizing rape by nonphysical

230. See supra notes 103-12 and accompanying text.

231. See supra notes 116-20 and accompanying text.

232. MPC DRAFT, supra note $1, \S 213.2(1)$ (a) cmt., at 47.

233. See supra notes 78-84 and accompanying text regarding "gentle nudge" and "hard shove." 
coercion when the threat leaves the person with no reasonable alternative but to engage in the sex act. This would be effected by: (1) enumerating context-specific circumstances in which there would a rebuttable presumption that the threatened person had no reasonable alternative, and thus, the threat was illegal and coercive and (2) including a general category criminalizing emotional, psychological, intellectual, or moral threats ${ }^{234}$ that leave the person no reasonable alternative.

Section 213.4(1) — sexual penetration by coercion - in the draft MPC provides a potential list of context-specific circumstances in which there would be a rebuttable presumption that the threat was illegal and coercive. Specifically, the following threats would be included:

(i) accuse anyone of ... a failure to comply with immigration regulations; or (ii) expose any information tending to [substantially] impair the credit or business repute of any person; or (iii) take or withhold action in an official capacity, whether public or private, or cause another person to take or withhold action in an official capacity, whether public or private; or (iv) inflict any substantial economic or financial harm that would not benefit the actor .... ${ }^{235}$

Unlike section 213.4(1)(a) of the draft MPC, however, threats in these circumstances would only create a rebuttable presumption that the threat was illegal and coercive. As discussed in Part III.B.2, the draft MPC provisions have the potential to be over-inclusive. If a person "obtained consent" by threatening one of the enumerated items, his or her conduct would be criminal under the statute. Under the approach proposed by this Comment, threatening one of the items would create a rebuttable presumption that the threatened person was left with no reasonable alternative, and thus, the threat was criminal, but it would not be conclusive. It would require further inquiry into whether the individual was left with no reasonable alternative.

Further, there are two modifications to the language from the draft MPC. First, threats to accuse anyone of a criminal offense are excluded. As discussed in Part III.B.2, including these types of threats has the potential to result in odd outcomes, such as whether an individual has committed sexual penetration by coercion depending on whether the state criminalizes adultery. ${ }^{236}$ Second, threats to expose information tending to impair a person's credit or business reputation are limited to threats tending to

234. The descriptions of these types of threats are based on the definition of "forcible compulsion" as the phrase is used in Pennsylvania's rape statute. See 18 PA. Cons. STAt. $\S \S 3101$, 3121 (Supp. 2014).

235. MPC DRAFT, supra note 1, § 213.4(1)(a), at 69.

236. See supra notes $228-30$ and accompanying text. 
substantially impair a person's credit or business reputation. This addition may be unnecessary given that threats would only be considered illegal when they leave the threatened person with no reasonable alternative. However, including substantially would help emphasize that the threat must be material.

Identifying specific circumstances where it is more likely the threat is illegal and coercive helps more clearly define the parameters of when a threat is impermissibly coercive. However, limiting criminalization to only those circumstances increases the likelihood the law will be under-inclusive. To address this possibility, the law should include a general category criminalizing emotional, psychological, intellectual, or moral threats ${ }^{237}$ that cause a person to engage in the sex act if the threat left the person no reasonable alternative.

Requiring that the threat left the person with no reasonable alternative draws from the contract law doctrine of duress. ${ }^{238}$ Under the Restatement (Second) of Contracts, a contract is voidable due to duress "[i]f a party's manifestation of assent is induced by an improper threat by the other party that leaves the victim no reasonable alternative." 239 As noted by Spence, contract law "incorporates both objective and subjective measures of the threat." ${ }^{240}$ Likewise, whether the emotional, psychological, intellectual, or moral threat left the person with no reasonable alternative should be considered from both a subjective and objective perspective.

Finally, rape by nonphysical coercion due to a threat under one of the context-specific circumstances or threats under the general category should be graded less severely than rape involving physical force, but significantly more harshly than blackmail or extortion. The lesser grading is not meant to trivialize the experience of rape by nonphysical coercion, ${ }^{241}$ but rather recognizes that expanding the scope of rape as proposed would be a significant change for many jurisdictions and attempts to make the change

237. The descriptions of the types of threats noted are based on the definition of "forcible compulsion" as used in Pennsylvania's rape statute. See 18 PA. Cons. STAT. §§ 3101, 3121.

238. See supra notes $106-08$ and accompanying text.

239. RESTATEMENT (SECOND) OF CONTRACTS § 175(1).

240. Spence, supra note 87 , at 80-81.

241. In discussing the costs and benefits of expanding rape law to include coercion and fraud, Professor Falk notes that one potential cost is trivializing the experience of violent rape. Falk, Rape, supra note 59, at 143. She also notes, however, that "statutes [that] grade violent rape more harshly and punish it more severely[] preserv[e] the judgment that it is a qualitatively more serious offense and forestall[] any possible hint of trivialization." Id. at 150. After discussing the considerations related to expanding rape law to include coercion and fraud, she concludes the benefits outweigh the costs. Id. at 156 . 
more of "gentle nudge" rather than a "hard shove."

\section{Applying the Blended, Incremental Approach}

Applying the approach proposed in this Comment helps to demonstrate its benefits as well as identify its drawbacks. Assuming the facts in Brooks, the outcome under the approach proposed in this Comment would likely be the same as under the highly subjective standard, but the analysis in reaching that result would differ.

Specifically, the analysis would begin by determining whether the threat was within any of the context-specific circumstances. During the trial, J.P. testified that she did not believe she would be fired or suffer direct adverse employment consequences as a result of the affair being exposed, but she did not want it exposed and believed it would taint the workplace environment. $^{242}$ Thus, the threat would not fall within the category of a threat to inflict substantial economic or financial harm or the category of a threat to expose information tending to substantially impair the credit or business repute of a person. Further, Brooks did not threaten to accuse J.P. of failure to comply with immigration regulations or to take or withhold action in an official capacity. ${ }^{243}$ As a result, Brooks's conduct would not fall within one of the context-specific circumstances in which there would be a rebuttable presumption that J.P. had no reasonable alternative, and thus, the threat was illegal and coercive.

Unlike the proposed MPC statute, however, the analysis would not stop here. Rather, it would be necessary to consider if Brooks made emotional, psychological, intellectual, or moral threats that left J.P. with no reasonable alternative but to engage in the sex act. Whether J.P. had a reasonable alterative would be considered from a subjective and objective perspective. In both instances, the analysis would be focused on whether the alternative is reasonable. Even if there were other alternatives, were they reasonable? Subjectively, the analysis would be similar to the court's analysis in Brooks. J.P. testified that she believed Brooks would follow through with his threat if she did not comply, and she only had sex because of this threat. ${ }^{244}$ One of J.P.'s

alternatives would have been refusing to have sex and having Brooks expose the affair. Subjectively and objectively, however, this is arguably

\footnotetext{
242. State v. Brooks, 265 P.3d 1175, 1180 (Kan. Ct. App. 2011), rev'd 317 P.3d 54 (Kan. 2014).

243. Id.

244. Id.
} 
not a reasonable alternative. Rather, Brooks put J.P. in a situation of choosing between an unreasonable threat and an unreasonable alternative, and thus, his threat was illegal and coercive.

As a result, applying the appellate standard of review_-"review[ing] the evidence in a light most favorable to the State to determine whether a rational factfinder could have found the defendant guilty beyond a reasonable doubt" ${ }^{245}$ - it seems likely the same result would be reached under the approach proposed in this Comment as under the highly subjective standard. Brooks would be guilty of rape. It also seems likely that the jury that originally found Brooks guilty rape would similarly find Brooks guilty of rape by nonphysical coercion.

While the outcomes would likely be the same under both approaches, the analysis leading to the result would differ as demonstrated above. Under the highly subjective standard, no consideration was given to J.P.'s alternatives - the only question was whether J.P. was subjectively overcome by fear. The more nuanced approach outlined here takes into account additional factors - was the threat of a type where it was more likely to be coercive and did the victim have reasonable alternatives. These further considerations help narrow the scope of the broad and over-inclusive highly subjective standard.

Consider again the list of other potential threats that could be criminal under the highly subjective standard as discussed in Part III.A.2:

[A] police officer's threat to arrest or offer not to make a justifiable arrest; a job supervisor's intention to fire an employee, block a promotion, or expedite an undeserved promotion; a threat to expose another person's adultery, embezzlement, irregular immigration status, or sexual orientation; a wealthy person's threat to stop supporting a paramour; $[\text { or }]_{246}$ a person's threat to break off a dating relationship ....

Under the highly subjective standard of Brooks, a defendant could be guilty of rape if the victim was overcome by fear due to any of these threats. The approach proposed in this Comment will not definitively classify a threat as permissible or impermissible — nor should it — but it will provide a more detailed framework within which to analyze and distinguish between legal—albeit morally suspect — threats and illegal threats.

245. State v. Brooks, 317 P.3d 54, 65 (Kan. 2014).

246. MPC DRAFT, supra note $1, \S 213.4(1) \mathrm{cmt}$., at 70. 


\section{Reflecting on the Proposed Approach}

The approach outlined in this Comment takes into account many of the issues identified with other alternatives and would provide Kansas with a more clearly defined standard that would lead to more predictable results and better guide behavior. It is not, however, the only acceptable approach to criminalizing rape by nonphysical coercion, and it has its own shortcomings. Nonetheless, "[t]he law must [ultimately] choose, from among empirically imperfect standards, the one best able to guide behavior and minimize the cost of inevitable over- and under-inclusiveness."247 The proposed approach is an attempt to do just this.

The dual-approach to criminalizing rape by nonphysical coercionincluding context-specific circumstances as well as a general category criminalizing nonphysical coercion-would provide for greater certainty and minimize the potential for the law to be over-inclusive. By enumerating specific limited circumstances where there would be rebuttal presumption that the threat was coercive and illegal, the law outlines situations where there is a higher likelihood of a coercive threat. This would not only assist the fact finder in analyzing a particular case, but would also put people on notice as to unacceptable criminal actions and better guide behavior.

Further, considering whether the threatened individual was left with no reasonable alternative but to engage in the sex act from both a subjective and objective perspective would limit the potential over-inclusiveness of the law - an issue with many of the alternatives discussed in this Comment. Neither the statute proposed in the draft MPC nor the highly subjective standard provides limits on the scope of threats that could be criminal. If an individual was "overcome by fear" due to her boyfriend's threats to break up with her, should his threats be criminal? Should a threat to "expose any information tending to impair the credit or business repute of any person" be criminal without a de minimis threshold? ${ }^{248}$

While many people would likely respond "no" to both of the questions above, requiring that the threatened person was left with no reasonable alterative may be controversial. The other party making the threat put himself or herself in the wrong by making the threat. Why should the threatened person be required to prove there were no reasonable alternatives? Considering several of the hypothetical threats, however,

247. Id. §213.2(1)(a) cmt., at 47.

248. MPC DRAFT, supra note $1, \S 213.4(1)(\mathrm{a})(\mathrm{ii})$, at 69 (emphasis added); see also supra note 224 and accompanying text. 
illustrates that the analysis is not so simple. Interpersonal relationships are complex. What crosses the line from persuasion to coercion is not always clear. Categorically criminalizing threats, without examining the broader circumstances would be unwise. Considering the reasonable alternatives helps define at what point the behavior crosses the line to being illegal.

Finally, in an effort to strike the balance between appropriately criminalizing coercive threats, while not being over-inclusive, the approach inevitably becomes more complex. The analysis would require consideration of both the context-specific circumstances and the general category. Further, in all instances, the fact finder would need to consider whether the threatened individual had a reasonable alternative from both subjective and objective perspective. This complexity, however, is what would allow the law the better define unacceptable, coercive behavior and also limit the potential for over-inclusiveness.

Reasonable scholars, commentators, and practitioners will disagree over how to best define the parameters of the law. While the approach proposed in this Comment has its own shortcomings, it addresses many of the drawbacks of potential alternatives. Further, not only would the proposed approach provide Kansas with a more clearly defined standard, it also offers another available option to be considered, discussed, and refined as the law continues to evolve.

\section{CONCLUSION}

Rape by nonphysical coercion should be criminalized. The challenge for the law, however, is how to define what behavior constitutes rape by nonphysical coercion. When does a person's conduct cross the line from permissible persuasion, or even a morally suspect, but arguably legal threat, to illegal coercion? The highly subjective standard of Brooks does little to help define this point, but rather provides an unclear standard that could lead to a lack of predictable results and an over-criminalization of conduct.

This Comment analyzed approaches taken in states that criminalize rape by nonphysical coercion and alternatives presented by scholars. Considering the benefits, but also the critiques of the various approaches, this Comment proposed a blended, incremental approach to criminalizing rape by nonphysical coercion. This approach would provide Kansas with a more clearly defined standard that would lead to more predictable results, better guide behavior, and more appropriately balance the ongoing challenge of being neither too over- or under-inclusive. 